\title{
Crohn hastalığı ve intestinal tüberküloz birlikteliği
}

\author{
Combination of Crohn's disease with intestinal tuberculosis
}

Muhammet Yener AKPINAR ${ }^{1}$, Yasemin ÖZDERIN ÖZIN ${ }^{1}$, Seda YAMAK², Ertuğrul KAYAÇETIN ${ }^{1}$

Türkiye Yüksek Ihtisas Eğitim ve Araştırma Hastanesi, ${ }^{1}$ Gastroenteroloji Kliniğĭ, ${ }^{2}$ Patoloji Bölümü, Ankara

Tüberküloz gelişmekte olan ülkelerde halen önemli bir sağllk sorunudur. Ekstrapulmoner tüberküloz bir çok organı etkileyebilir. Gastrointestinal sistem tüberkülozu \%3-5 ile sık izlenilmeyen bir ekstrapulmoner tüberküloz nedenidir; sıklıkla tüberküloz enteriti ve tüberküloz peritoniti olarak karşımıza çıkar. Tüberküloz enteriti ile Crohn hastalığı ayrımı önemlidir. Günümüzde Crohn hastalığının tedavisinde merkezde immünsüpresif ilaçlar yer almaktadır. Bu nedenle bu ayrım hayati önem taşımaktadır.

Anahtar kelimeler: Crohn hastalığı, intestinal tüberküloz

\section{GİRİş}

Crohn hastalığı ağızdan anüse kadar gastrointestinal sistemin herhangi bir kısmını etkileyebilen kronik inflamatuvar bir barsak hastalığıdır. Ileoçekal bölge hastalıktan en çok etkilenen bölgedir. Yıllar içinde Crohn hastalığının tedavisinde önemli değişmeler olmuştur. Günümüzde anti tümör nekrozis faktör (anti-TNF) ilaçlar hastalık tedavisinde yaygın olarak kullanılan ve mukozal iyileşmeyi sağlayan temel ilaçlardır (1). Immünsüpresyon sağlayan bu ilaçları alan hastaların tüberküloz basili ile karşılaşma durumu iyi bilinmeli, basil ile daha önce karşılaşan hastalara pürifiye protein derivatifi (PPD) durumuna göre profilaktik izoniyazid başlanılmalıdır. Biz burada tüberküloz enteriti hikayesi olan ve bu yüzden antitüberküloz tedavi alan bir hastada gelişen Crohn hastalığını sunduk.

\section{OLGU SUNUMU}

Otuz sekiz yaşında erkek hasta hastanemize karın ağrısı, kilo kaybı, aralıklı bulantı ve kusma şikayetleri ile başvurdu. Özgeçmişinde 20 yıl önce akciğer tüberkülozundan dolayı tedavi gördüğü öğrenilen hasta 9 ay önce de karın ağrilarından dolayı tetkik edilmişti. Kolonoskopisinde çekumda ülseratif lezyonu tespit edilen hastanın buradan alınan biyopsisi kazeifikasyon nekrozu içeren granülomlar göstermiş ve hastaya tüberküloz enteriti tanısı konulmuştu. Hastaya bu tanı ile antitüberküloz tedavi başlanılmıştı. Hastanın antitüberküloz tedavisi altında karın ağrıları belirgin hale gelmiş; ilave olarak bulantı ve kusmaları gelişmişti. Hastanemizdeki laboratuvar
Tuberculosis is an important health care problem in developing countries. Extrapulmonary tuberculosis can affect many organs. However gastrointestinal tuberculosis is a rare condition with 3-5\% frequency. Tuberculosis enteritis and tuberculosis peritonitis are the major clinical manifestations of gastrointestinal tuberculosis. Differential diagnosis between Crohn's disease and tuberculosis enteritis is important. Immunsupresive treatments including anti-tumour necrosis factors are the leading treatment modalities in Crohn's disease. Therefore distinction between these conditions is crucial.

Key words: Crohn's diease, intestinal tuberculosis

tahlillerinde hemoglobin (Hgb):12,3 gr/dl, lökosit: 6300x10³/ uL, platelet: $359.000 \times 10^{3} / \mathrm{uL}$, alanin aminotransferaz (ALT):7 $\mathrm{U} / \mathrm{L}$, aspartat aminotransferaz (AST): $12 \mathrm{U} / \mathrm{L}$, gama glutamil transferaz (GGT): 17 U/L, alkalin fosfataz (ALP): 96 U/L, C-reaktif protein (CRP): $94 \mathrm{mg} / \mathrm{L}$ ve sedimentasyon: $33 \mathrm{~mm} / \mathrm{saat}$ olarak izlendi. Batın ultrasonografisinde ince barsaklarda dilatasyona rastlandı. Hastaya yapılan kolonoskopide tüm kolon normal olarak değerlendirildi, terminal ileumda $20 \mathrm{~cm}$ kadar ilerlendi ancak burada da patolojiye rastlanılmadı. Ince barsak pasaj grafisinde distal jejunal ve proksimal ileal looplarda uzun segment, en geniş yerinde $6,3 \mathrm{~cm}$ ölçülen dilatasyon izlendi. Takibinde hastaya kontrastll trifazik abdomen tomografisi çekildi. Burada da ince barsaklarda en geniş yerinde $5 \mathrm{~cm}$ 'e ulaşan dilatasyonlara rastlandı (Resim 1). Ayrıca distal ileuma ait olduğu düşünülen yerde en kalın yerinde 8.5 mm'ye ulaşan duvar diffüz duvar kalınlaşması izlendi. Hastanın hastalıklı barsak bölgesine kolonoskopi ile ulaşlamaması, sık sık karın ağrısı ile beraber subileus atakları ile acile başvurmasından dolayı hasta opere edildi. Ileumdan $80 \mathrm{~cm}$ proksimalde dilatasyona neden olan yaklaşı 30 cm'lik kısım rezeke edildi. Biyopside makroskopik olarak yer yer hiperemi ve ülserler izlendi. Mikroskopik incelemede ise mukozal ülserlerin yanında kript apselerine rastlandı (Resim 2). Lamina propriyada lenfoplazmositik infiltrasyon ve eozinofiler izlendi. Bu bulgulara ilave olarak transmural lenfosit agregatlar ve fibrozise rastlandı. Granülomlara rastlanılmadı. Biyopsi sonucu hastaya Crohn hastalığı tanısı konuldu. 


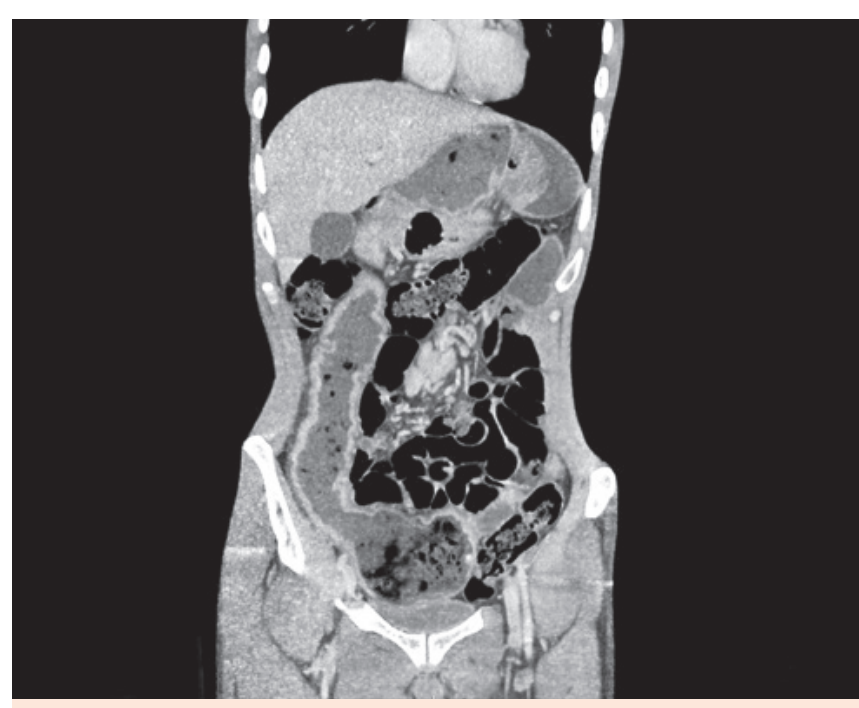

Resim 1. lleumda diffüz duvar kalınlaşması ve dilatasyon.

\section{TARTIŞMA}

Tüberküloz gelişmekte olan ülkelerde halen önemli bir sağlık sorunudur. Ekstrapulmoner tüberküloz bir çok organı etkileyebilir; tüberküloz lenfadenit en sık izlenilen ekstrapulmoner tüberküloz nedenidir (2). Gastrointestinal sistem tüberkülozu \%3-5 ile sik izlenilmeyen bir ekstrapulmoner tüberküloz nedenidir; sıklıkla tüberküloz enteriti ve tüberküloz peritoniti olarak karşımıza çıkar (3). Tüberküloz enteritinin epidemiyolojisi ve ortalama görülme yaşı bölgesel farklılıklar gösterebilir. Türkiye ve Pakistan gibi ülkelerde genç kadınlar daha sık etkilenir (4). Tüberküloz enteriti enfekte balgamın yutulması, enfekte gıdanın yenmesi veya hematojen yayılımla oluşabilir (5). Ileoçekal alan ve jejunoileum en sık lokalizasyon alanıdır. Endoskopik olarak lezyonlar kendini ülseratif, hipertrofik veya ülserohipertrofik olarak gösterebilir. Ülseratif lezyonlar \%60 ile en sık izlenen tiptir, multipl süperfisiyal ülserler ile karakterize olup ülserler barsak uzun eksenine transvers yerleşir (5). Hastalarda semptomlar tutulum yerine ve komplikasyonlara bağlı değişebilir. Kronik nonspesifik karın ağrısı \%80-90 ile en sık izlenen şikayettir. Diğer şikayetler arasında halsizlik, kilo kaybı, ishal ve gece terlemesi sayılır. Laboratuvar bulguları nonspesifiktir. Çoğu hastada orta dereceli anemi ve artmış sedimentasyon hızına rastlanılır (6). Fizik muayenede hastaların \%20-50 kadarında sağ alt kadranda kitle ele gelebilir (7). Asitin varlığı tüberküloz lehine

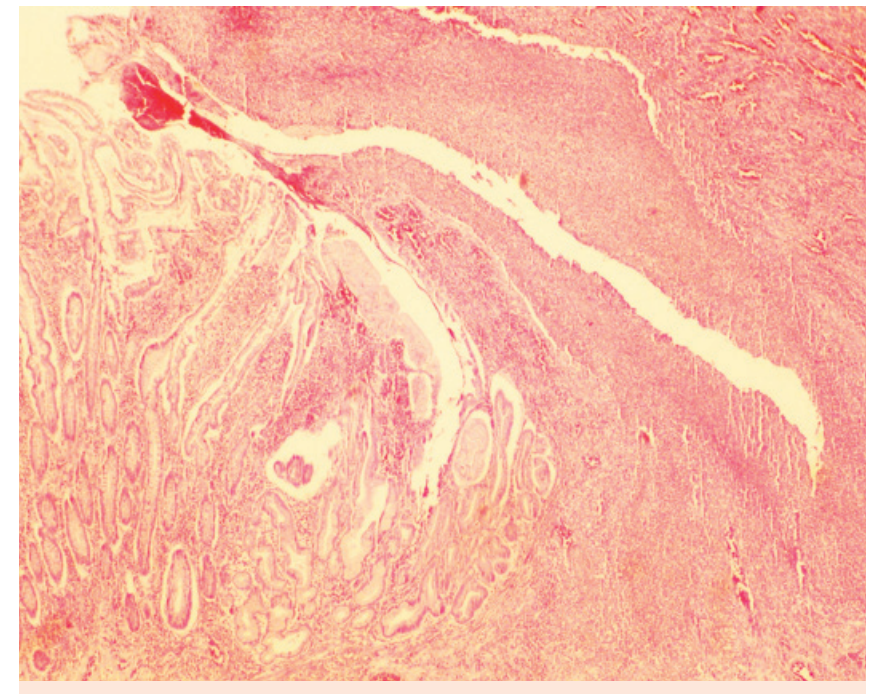

Resim 2. Inflamatuvar infiltratla çevrili fissür benzeri ülser.

yorumlanabilir, Crohn hastalığında asit daha nadirdir. Tanıda abdomen tomografisi en yararlı görüntüleme yöntemidir. Tomografi bulguları arasında ileoçekal bölgede duvar kalınlaşması, proksimal segmentlerde dilatasyon, hipodens merkezli lenfadenopatiler görülebilir (8). Tüberküloz enteriti komplikasyonları obstrüksiyon, perforasyon ve fistül formasyonu sayılabilir. Barsak obstrüksiyonu en sık izlenen komplikasyon olup ilerleyici progresif striktür ve adezyona bağlı oluşur (9).

Tüberküloz enteriti ile Crohn hastalığı ayrımı önemlidir. Günümüzde Crohn hastalığının tedavisinde merkezde immünsüpresif ilaçlar yer almaktadır. Bu nedenle bu ayrım hayati önem taşımaktadır. Her iki hastalığın başlangıcı yavaş seyirli olup hastalarda nonspesifik karın ağrıları görülür. Hastanın önceden tüberküloz geçirmiş olması, ailesinde tüberküloz geçiren yakınının olması ve immünsüpresif tedavi alması tüberküloz lehine yorumlanır. Patoloji her iki hastalığın tanısında da önemlidir. Her iki hastalık da granülomatöz inflamasyon ile katakterize olup kezaifikasyon nekrozu içeren granülomlar ve epiteloid histiyositlerle döşeli ülserler intestinal tüberküloz hastalığı lehine bulgulardır (10).

Sonuç olarak Crohn hastalığının gastrointestinal sistemin herhangi bir kısmında görülebileceği akılda tutulmalı; jejunum veya ileumda izlenilen ülser, darlık ve duvar kalınlaşmaları Crohn hastalığı açısından da tetkik edilmelidir. 


\section{KAYNAKLAR}

1. Fernandes C, Allocca M, Danese S, Fiorino G. Progress with anti-tumor necrosis factor therapeutics for the treatment of inflammatory bowel disease. Immunotherapy 2015;7:175-90.

2. Golden MP, Vikram HR. Extrapulmonary tuberculosis: an overview. Am Fam Physician 2005;72:1761-8.

3. Chong VH, Lim KS. Gastrointestinal tuberculosis. Singapore Med J 2009;50:638-45.

4. Donoghue HD, Holton J. Intestinal tuberculosis. Curr Opin Infect Dis 2009;22:490-6.

5. Marshall JB. Tuberculosis of the gastrointestinal tract and peritoneum Am J Gastroenterol 1993;88:989-99.
6. Kapoor VK. Abdominal tuberculosis. Postgrad Med J 1998;74:459-67.

7. Horvath KD, Whelan RL. Intestinal tuberculosis: return of an old disease. Am J Gastroenterol 1998;93:692-6.

8. Balthazar EJ, Gordon R, Hulnick D. Ileocecal tuberculosis: CT and radiologic evaluation. AJR Am J Roentgenol 1990;154:499-503.

9. Ha HK, Ko GY, Yu ES, et al. Intestinal tuberculosis with abdominal complications: radiologic and pathologic features. Abdom Imaging 1999;24:32-8

10. Pulimood AB, Ramakrishna BS, Kurian G, et al. Endoscopic mucosal biopsies are useful in distinguishing granulomatous colitis due to Crohn's disease from tuberculosis. Gut 1999;45:537-41. 